\title{
The effects of a changing pollution climate on throughfall deposition and cycling in a forested area in southern England
}

Article

Accepted Version

Skeffington, R. and Hill, T. (2012) The effects of a changing pollution climate on throughfall deposition and cycling in a forested area in southern England. Science of the Total Environment, 434. pp. 28-38. ISSN 0048-9697 doi: https://doi.org/10.1016/j.scitotenv.2011.12.038 Available at https://centaur.reading.ac.uk/28657/

It is advisable to refer to the publisher's version if you intend to cite from the work. See Guidance on citing.

Published version at: http://www.sciencedirect.com/science/journal/00489697

To link to this article DOI: http://dx.doi.org/10.1016/j.scitotenv.2011.12.038

Publisher: Elsevier

All outputs in CentAUR are protected by Intellectual Property Rights law, including copyright law. Copyright and IPR is retained by the creators or other copyright holders. Terms and conditions for use of this material are defined in the End User Agreement.

www.reading.ac.uk/centaur 
Central Archive at the University of Reading

Reading's research outputs online 


\title{
The effects of a changing pollution climate on throughfall deposition and cycling in a forested area in southern England
}

\author{
${ }^{1}$ R. A. SKEFFINGTON ${ }^{*},{ }^{1}$ T. J. HILL \\ ${ }^{I}$ Department of Geography and Environmental Science, University of Reading, PO Box 227, \\ READING RG6 6DW UK;
}

*Corresponding author

Telephone: $\quad+441183787323$;

Fax: $\quad$ +44 1189755865 ;

email: r.a.skeffington@ reading.ac.uk

\begin{abstract}
.
This study compares two sets of measurements of the composition of bulk precipitation and throughfall at a site in southern England with a 20-year gap between them. During this time, $\mathrm{SO}_{2}$ emissions from the UK fell by $82 \%, \mathrm{NO}_{\mathrm{x}}$ emissions by $35 \%$ and $\mathrm{NH}_{3}$ emissions by $7 \%$. These reductions were partly reflected in bulk precipitation, with deposition reductions of $56 \%$ in $\mathrm{SO}_{4}{ }^{2-}, 38 \%$ in $\mathrm{NO}_{3}{ }^{-}, 32 \%$ in $\mathrm{NH}_{4}{ }^{+}$, and $73 \%$ in $\mathrm{H}^{+}$. In throughfall under Scots pine, the effects were more dramatic, with an $89 \%$ reduction in $\mathrm{SO}_{4}{ }^{2-}$ deposition and a $98 \%$ reduction in $\mathrm{H}^{+}$deposition. The mean $\mathrm{pH}$ under these trees increased from 2.85 to 4.30. Nitrate and ammonium deposition in throughfall increased slightly, however. In the earlier period, the Scots pines were unable to neutralise the high flux of acidity associated with sulphur deposition, even though this was not a highly polluted part of the UK, and deciduous trees (oak and birch) were only able to neutralise it in summer when the leaves were present. In the later period, the sulphur flux had reduced to the point where the acidity could be neutralised by all species - the neutralisation mechanism is thus likely to be largely leaching of base cations and buffering substances from the foliage. The high fluxes are partly due to the fact that these are 60-80 year old trees growing in an open forest structure. The increase in $\mathrm{NO}_{3}{ }^{-}$and $\mathrm{NH}_{4}{ }^{+}$in throughfall in spite of decreased deposition seems likely due to a decrease in foliar uptake, perhaps due to the increasing nitrogen saturation of the catchment soils. These changes may increase the rate of soil microbial activity as nitrogen increases and acidity declines, with consequent effects on water quality of the catchment drainage stream.
\end{abstract}

Keywords: Throughfall; nitrogen cycling; acid deposition; emission reductions; Scots pine; bracken; oak; birch.

\section{Introduction}

It has long been recognised that, in forested areas, both the quantity and quality of precipitation is significantly altered by contact with the surfaces of the trees. The study of 
throughfall (precipitation which falls through the tree canopy) has a long history, reviewed for instance by Parker (1983) and more recently by Levia and Frost (2006). Though there are still gaps in knowledge (Levia and Frost, 2006) a large number of studies have identified the main features and importance of throughfall in nutrient cycling. Precipitation falling towards the canopy has three fates: it somehow misses any contact with a vegetative surface and falls to the ground unchanged (sometimes called "free throughfall"); it is intercepted by the canopy and evaporated before reaching the ground ("interception loss") or it is intercepted and subsequently drips off (numerous terms including "release throughfall" (Levia and Frost, 2006), or "canopy drip" (Parker, 1983); or it runs to the ground down the tree bole ("stemflow"). Chemically, the canopy drip is influenced by a number of processes. The incident precipitation contributes dissolved substances. Gases and particulates deposit on the canopy (dry deposition) and are subsequently washed off . Substances are leached from inside the tree via the foliage, and leaves can also take up substances from the gaseous phase or water films. Foliar uptake of nitrogen species is particularly significant (Sparks, 2009). Epiphytes and micro-organisms growing on canopy surfaces can also play a role in altering the composition of throughfall. Much research has gone into quantifying the relative importance of these processes under different circumstances, and models encapsulating the influence of canopy exchange and dry deposition on throughfall composition have been developed and tested (e.g. Staelens et al. 2008). For many elements, notably K, Na, Cl and S, but also others in some situations, throughfall is the major pathway by which nutrients reach the forest floor, exceeding the flux in litterfall (Parker, 1983). The distribution and composition of throughfall has a profound effect on soil chemical and moisture characteristics and on the organisms which live in the soil, either directly (e.g. Moffat et al., 2002) or via a strong interaction with soil properties (e.g. Raat et al. 2002). 
Tamm and Cowling (1977) were the first to suggest that acid deposition could disrupt nutrient cycling in throughfall. The subject has been studied extensively since, using large scale synoptic surveys (e.g. Lindberg and Lovett, 1992), controlled open-air fumigations (Skeffington and Sutherland, 1985), and international collaborative programmes of research (e.g. ICP Forests, UNECE, 2010) and it is clear that acid deposition can produce profound changes in the rates of nitrogen, sulphur and base cation recycling. This paper is a study of the effect of a dramatically changing pollution climate on precipitation and throughfall composition at the same site in southern England, with a 20-year gap between sets of measurements. During that period, there was a large reduction in emissions of $\mathrm{SO}_{2}$ and oxides of nitrogen in the UK (82\% and 35\% respectively - see Table 1) and in Europe as a whole (68\% and 27\% respectively: Fowler et al., 2007). This was driven by legislation such as successive international agreements under the UNECE Convention on Long-Range Transboundary Air Pollution (UNECE, 2011) and EU legislation mandating reductions from large combustion plants (EU, 1988), and at the very end of the period, setting emission limits on EU countries (EU, 2001). This legislation was motivated by the need to reduce the effects of these acidifying and eutrophying pollutants on ecosystems and human health. Economic factors also played a part, particularly the extensive replacement of coal by gas in power generation (NAEI, 2011). The third acidifying/eutrophying pollutant, ammonia, was reduced by a smaller amount (c. 7\% in the UK, 22\% in Europe; Table 1 and Fowler et al. 2007). The pollution climate experienced by ecosystems was not however linearly related to these changes. The decreasing ratio of $\mathrm{SO}_{2}$ to $\mathrm{NH}_{3}$ has increased $\mathrm{SO}_{2}$ deposition velocities over most areas of the UK, including the site of this study (Fowler et al., 2005, 2007). Models predict that dry deposition of S should have declined in the study area much more than wet deposition, and this should result in a large reduction in throughfall deposition. The nonlinearities in oxidised $\mathrm{N}$ deposition are not fully understood, but in the study area, in contrast 
to $\mathrm{S}$, deposition of $\mathrm{NO}_{3}{ }^{-}$would be expected to reduce by less than the reduction in emissions (Fowler et al., 2005, 2007).

This paper explores the effects these changes had on precipitation and throughfall composition, and their implications for catchment soils and waters. The aims of the study included a comparison of throughfall under three tree species (Scots pine, silver birch and English oak), including the provision of an explanation of the very high acidity in Scots pine throughfall, and an evaluation of the cycling of a number of different elements in Scots pine throughfall.

\section{Methods}

This paper compares data collected during two study periods: 1979-82 and 1999-2003 (Hill et al., 2002). Although some attempt was made to make the methods comparable, the two studies had somewhat different objectives, and technological advances increased the possibilities in the later period.

\subsection{SITE DESCRIPTION}

The site was fully described by Hill et al. (2002): an abbreviated description follows. The Tillingbourne catchment is located $7 \mathrm{~km}$ south west of Dorking in SE England, Latitude $51^{\circ}$ $11 \square$ N., Longitude $0^{\circ} 22 \square$ W. (Fig.1). It consists of a valley sloping northwards at an angle of about $3^{\circ}$, cut into the dip slope of Leith Hill (297m), the highest point of SE England. There are no motor roads or habitations in the catchment, but the area is heavily used for informal recreation by walkers and horse-riders. The catchment is composed of sedimentary rocks of Cretaceous age, the Lower Greensand Group. The Atherfield Clay which outcrops in the bottom of the valley consists of shales and mudstones which weather to a silty clay with a very low permeability to water. The soils that develop on this formation are classified as 
argillic humic gleysoils (humic gleysols in the WRB System (FAO, 2011)). Overlying the Atherfield Clay is the Hythe Formation, which consists of coarse, porous, non-calcareous sandstones which weather to very acidic humo-ferric podzols (orthic podzols in the WRB System; FAO, 2011). Throughfall was collected under trees close to the boundary of these two formations.

\section{Fig. 1 near here}

The vegetation of the area is mixed coniferous-deciduous forest. Trees cover about $89 \%$ of the catchment, the main species being Scots pine (Pinus sylvestris L.); oak (Quercus robur L.) and birch (Betula pendula Roth). There are occasional trees of other species. On the basis of annual ring counts, most trees date from about 1920, indicating that any large trees formerly present were felled during the 1914-18 war, a common fate for British trees. The area was then left to recover spontaneously, so the trees are self-sown, giving an open canopy structure. In the area of throughfall collection, ground vegetation is overwhelmingly dominated by bracken (Pteridium aquilinum (L) Kuhn), which suppresses other ground cover. There were few changes in vegetation between the two study periods: the trees of course grew larger but growth rates for mature trees on this poor soil are quite slow.

\subsection{RAINFALL AND THROUGHFALL COLLECTION}

Bulk precipitation in both periods was collected at two sites within the catchment, at Sites F and $\mathrm{G}$ in Figure 1. These were $325 \mathrm{~m}$ apart, and Site F is $22 \mathrm{~m}$ higher in altitude than Site G. In both years the collector was mounted $1.5 \mathrm{~m}$ above the ground surface. In 1978-82 it was a borosilicate glass funnel $198 \mathrm{~mm}$ in diameter with underground polyethylene storage bottle. In 1999-2003 it was a "Warren Spring" bulk precipitation collector as used in the UK Acid Deposition Monitoring Network (see Hill et al. 2000). This consisted of a polyethylene 
funnel $152.4 \mathrm{~mm}$ in diameter with bird guard and above-ground storage. In both cases water was collected weekly.

Throughfall collection differed significantly between the two periods. From 8 February 1979 to 8 February 1982, 18 throughfall collectors were installed in a 2 ha area near the upper flow gauge (around $\mathrm{H} 2$ in Figure 1). These collectors were arranged in a stratified random design using co-ordinates derived in advance from random number tables, and thus provide an estimate of overall throughfall composition in this part of the catchment. Six collectors were below oaks; six below birches; three below pines; two below bracken; and one below a sweet chestnut. The collectors consisted of polyethylene funnels $127 \mathrm{~mm}$ in diameter situated 200 mm above the ground surface, with an underground polythene bottle underneath. In 19992003, throughfall was initially collected only under Scots pines, two in the lower part of the catchment (H1 in Figure 1) and two in the 1979-82 sampling area (H2), again starting on 8 February. Samples were bulked before analysis. For comparison with the older data, a collection under the same Scots pine trees as originally used in 1979-82 was conducted from February 2002 to February 2003, with collectors in the same positions as determined from original photographs and measurements. The collected volumes were bulked for analysis. The throughfall collectors for 1999-2003 were polyethylene funnels $152.4 \mathrm{~mm}$ in diameter and were supported by external unplasticised polyvinyl chloride piping $400 \mathrm{~mm}$ above the ground surface, leading into an underground storage bottle. Samples were collected weekly.

\subsection{GAS CONCENTRATIONS}

Concentrations of ammonia and nitrogen dioxide were measured using diffusion tubes. These are short plastic tubes which are exposed to ambient air for fixed periods. An absorbent material is placed at the end of a tube and molecular diffusion allows the gas to pass towards 
the material. The rate of absorption is proportional to the ambient concentrations, giving a mean concentration over the exposure period. The measurement protocol followed that for the UK Nitrogen Diffusion Tube Network (Bush et al., 2000). A set of four diffusion tubes was used at each rainfall collection site, two for $\mathrm{NO}_{2}$ and two for $\mathrm{NH}_{3}$. The tubes were located on the precipitation collectors at a height of $1.5 \mathrm{~m}$. The $\mathrm{NO}_{2}$ tubes were exposed for 2 weeks and the $\mathrm{NH}_{3}$ tubes for 4 weeks. Measurements were made for 2 years from March 2001. "Travel blank" samples were also analysed to check for contamination - these were subject to the same handling procedures as the experimental tubes but were not exposed to the atmosphere. After return to the laboratory, the tubes were sent for analysis to Gradko International Ltd, which also supplied the tubes.

\subsection{CHEMICAL ANALYSIS}

In 1979-82 fewer determinands were measured than in 1999-2003, and updated methodology was used in the later period. In 1979-1982, analyses were performed at the Central Electricity Research Laboratories, from 1999 to 2000 at CEH Wallingford except for $\mathrm{pH}$, alkalinity and conductivity, which were measured at the University of Reading, where all analysis was performed after January 2001.

On the day of collection, $\mathrm{pH}$ was measured in the laboratory using a Radiometer $\mathrm{pH}$ meter and combination electrode, and conductivity by a standard conductivity meter at $25^{\circ} \mathrm{C}$. From 1999, alkalinity was also measured on collection day by modified Gran titration (Neal, 2000). The remaining samples were stored in the dark at $4{ }^{\circ} \mathrm{C}$, and analysis normally completed within a week. On arrival at the laboratory, the sample destined for cation analysis was acidified using Aristar® nitric acid to $1 \% \mathrm{v} / \mathrm{v}$, to reduce adsorption and precipitation. Metal cations were determined on an inductively coupled plasma - optical emission spectrograph 
(ICP-OES). The instrument was run using a low range, high sensitivity method, (ultrasonic nebuliser) and repeated using a lower sensitivity, higher range (cross-flow) method for higher concentration elements. Elements routinely analysed were $\mathrm{Al}, \mathrm{Ba}, \mathrm{Ca}, \mathrm{Cu}, \mathrm{Fe}, \mathrm{K}, \mathrm{Mg}, \mathrm{Na}, \mathrm{S}$, Sr, and $\mathrm{Zn}$. Ammonium was determined by continuous segmented flow analysis with sodium salicylate / sodium nitroprusside reagent, with a sensitivity of $0.01 \mathrm{mg} \mathrm{N} \mathrm{L}^{-1}$. Anions were analysed with a "Dionex" ion chromatograph set up to detect $\mathrm{F}^{-}, \mathrm{Cl}^{-}, \mathrm{Br}^{-} \mathrm{NO}_{3}{ }^{-}$and $\mathrm{SO}_{4}{ }^{2-}$. Dissolved organic carbon (DOC) was determined directly by combustion in commercial DOC analysers - a Tocsin II aqueous carbon analyser at Institute of Hydrology and a Shamadzu 5000 carbon analyser at University of Reading.

In 1979-82 a reduced set of determinands were measured: $\mathrm{pH}$, conductivity and $\mathrm{NH}_{4}{ }^{+}$as above and $\mathrm{Cl}^{-}, \mathrm{NO}_{3}{ }^{-}$and $\mathrm{SO}_{4}{ }^{2-}$ by automated colorimetric methods. Chloride was measured by an automated method involving the release of thiocyanate ions from mercuric thiocyanate, and reaction with ferric nitrate to form ferric thiocyanate, which was measured at $540 \mathrm{~nm}$. Sulphate was analysed by an automated method (Dimmock, Garbett and Webber, 1981) in which $\mathrm{SO}_{4}{ }^{2-}$ reacted with barium ions in 70\% propan-2-ol to form insoluble barium sulphate. The residual barium was then quantitatively complexed by the ligand nitrosulphonazo-III, and the reduction in absorbance was measured at $640 \mathrm{~nm}$. This method was shown to be comparable to ion chromatography when it was initially developed, using Tillingbourne rain and throughfall samples. Nitrate was measured by reduction to nitrite with copperhydrazinium sulphate followed by reaction with sulphanilimide and N-1napthylethylenediamine dihydrochloride to give a coloured complex measured at $520 \mathrm{~nm}$. This method measures nitrate + nitrite, but independent measurements of nitrite were always negligible. Dissolved organic matter was measured in 1979-82 using a double beam uv spectrometer ("Water Research Centre Organic Pollution Monitor"). This measures the 
aromatic component of organic matter, and was calibrated against organic matter extracted from the catchment stream by an anion exchange resin, desorbed by $\mathrm{pH} 2.0 \mathrm{HCl}$, and purified. This fraction is known in the water quality literature as "fulvic acid" (Stevenson, 1994). The method is not sensitive to all forms of organic carbon, and is thus not directly comparable with the combustion method used for DOC in 1999-2003.

\subsection{STATISTICAL ANALYSIS}

Statistical analysis was performed using the Minitab 16 statistical package (www.minitab.com). T-tests were used with appropriate checks for normality and equality of variances. Product-moment (Pearson) correlation coefficients were calculated for some variables as described in the Results section. Standard significance tests were used for both ttests and correlation coefficients.

\section{Results and Discussion}

\subsection{CHANGES IN BULK PRECIPITATION AND THROUGHFALL}

In this paper, concentrations are given in micro-equivalents per litre $\left(\mu \mathrm{eq} \mathrm{L}^{-1}\right)$ which is preferred to the more cumbersome but slightly more correct micro- mol of charge per cubic

decimetre $\left(\mu \mathrm{mol}_{\mathrm{c}} \mathrm{dm}^{-3}\right)$. Similarly deposition fluxes are in eq $\mathrm{ha}^{-1} \mathrm{yr}^{-1}-$ divide by 10 to obtain meq $\mathrm{m}^{-2} \mathrm{yr}^{-1}$

\subsubsection{Observed changes}

\section{Figures 2 and 3 near here}

Figure 2 shows that bulk precipitation deposition changed considerably between the two periods of 1979-1982 and 1999-2003: there was a 56\% reduction in sulphate deposition, a $38 \%$ reduction in nitrate, a $32 \%$ reduction in ammonium and a $73 \%$ reduction in $\mathrm{H}^{+}$. These are similar to those observed in national monitoring networks during the same time period. 
For throughfall the changes were even greater. Figure 3 shows several bases for comparison with the 1979-82 data. Compared to the four years from 1999, the reduction under Scots pine trees was $97 \%$ in $\mathrm{H}^{+}$and $79 \%$ in sulphate; nitrate however increased by $178 \%$ and ammonium by $152 \%$. These data were obtained under different trees from those in 1979-82: under the same trees for 2002 only, $\mathrm{H}^{+}$declined by $94 \%$ and sulphate by $75 \%$, nitrate increased by $96 \%$ and ammonium decreased by $25 \%$. For comparison, the corresponding figures for 2002 for the "new" Scots pines were decreases in $\mathrm{H}^{+}$and sulphate deposition of $96 \%$ and $77 \%$ and increases in nitrate and ammonium deposition of $167 \%$ and $53 \%$ respectively. The reactions of the old and new set of trees are thus consistent except for ammonium: throughfall under the old trees has higher concentrations of sulphate and nitrate and thus $\mathrm{H}^{+}$. It was not possible to calculate changes in "non-marine" sulphate for all years, but based on chloride, the decline in non-marine sulphate for the old Scots pines, 1982 versus 2002, was $78 \%$, only slightly higher than the decline in total sulphate.

\section{Figures 4 and 5 near here.}

Bulk precipitation and throughfall concentrations are also very relevant to macronutrient cycling. The volume-weighted mean concentrations are shown in Figures 4 and 5. Yearly values are shown to give an impression of annual variability. Mean rainfall volumes in the two periods were very similar (1098 and $1123 \mathrm{~mm}$ respectively), but variability was greater in the second period with alternating wet and dry years. Ammonium and nitrate concentrations in rain have an inverse pattern to rainfall (higher in dry years) indicating washout of a limited supply of atmospheric combined N, whereas this pattern does not occur with sulphate and $\mathrm{pH}$. Sulphate very clearly declined between the two periods and $\mathrm{pH}$ increased. Ammonium and nitrate decreased, but less obviously. If the annual mean values are taken as independent estimates of concentrations in their respective periods, then a t-test indicates the difference is highly significant for $\mathrm{pH}$ and sulphate $(\mathrm{p}<0.001)$, significant for 
nitrate $(\mathrm{p}<0.01)$ and ammonium $(\mathrm{p}=0.03)$ and not significant for precipitation volume $(p=0.44)$. The corresponding differences for deposition are all highly significant $(p<0.001$ except ammonium $(\mathrm{p}<0.01)$.

Throughfall concentrations (Figure 5) show a huge (89\%) decrease in sulphate and increase in $\mathrm{pH}\left(98 \%\right.$ decrease in $\left.\mathrm{H}^{+}\right)$, both highly significant $(\mathrm{p}<0.001)$. In contrast to rainfall there is a significant increase in volume $(\mathrm{p}=0.03)$ reflecting the different trees used, and the differences between periods in nitrate and ammonium concentrations are not significant $(\mathrm{p}=0.13$ and 0.24 respectively). Ammonium concentrations are variable and apparently decreasing. The differences between annual deposition in 1979-82 and 1999-2003 are however significant $(\mathrm{p}<0.001$ except ammonium $\mathrm{p}=0.04)$.

\subsubsection{Causes of Change}

\section{Table 1 near here}

The principal cause of the changes in $\mathrm{S}$ and $\mathrm{N}$ in bulk deposition is the reduction in emissions of the precursor gases (Table 1). These reductions are consequent on reductions of emissions of $\mathrm{SO}_{2}, \mathrm{NO}_{\mathrm{x}}$ and $\mathrm{NH}_{3}$ mandated by legislation as described in the Introduction. Between 1979 and 2003, $\mathrm{UK} \mathrm{SO}_{2}$ emissions declined by $82 \%, \mathrm{NO}_{\mathrm{x}}$ emissions by $35 \%$, and $\mathrm{NH}_{3}$ emissions by about $7 \%$. In addition, emissions fell year-on-year during the study periods (Table 1 ). Sulphate deposition in precipitation thus did not decline by as much as UK sulphur emissions. This is consistent with observations in the same region of the UK by the national precipitation monitoring networks (Fowler et al., 2005), though they extend these observations backwards in time since a national network was not established until 1986 . The non-linearity is thought to be due to changes in the relative amounts of $\mathrm{NH}_{3}$ and $\mathrm{SO}_{2}$ in the atmosphere (Fowler et al., 2001), and consequent changes in deposition rates (since ammonia and $\mathrm{SO}_{2}$ co-deposit (e.g. McLeod et al., 1990) and in sulphur oxidation rates. The decline in 
throughfall deposition of sulphate was comparable to the decline in $\mathrm{UK} \mathrm{SO}_{2}$ emissions. In the $\mathrm{UK}$ as a whole, dry deposition of $\mathrm{SO}_{2}$ has declined by more than the rate of reduction of emissions (Fowler et al., 2005), but this trend would not necessarily be seen at a single site which is affected by the spatial distribution of emissions over the UK and also by long-range transport from other countries.

The picture is different for the nitrogen species. Nitrate in bulk precipitation declined to a similar extent to the reduction in $\mathrm{UK} \mathrm{NO}_{\mathrm{x}}$ emissions. This contrasts with the national picture where the decline in deposition has generally been less than the decline in emissions (Fowler et al., 2005). Ammonium in precipitation has declined by more than the trend in national emissions would indicate (Figure 2), though ammonium is most likely to be affected by changes in local sources. In throughfall, however, nitrate and (less certainly) ammonium deposition have apparently increased (Figure 3). As it seems unlikely that dry deposition of the precursor gases would increase given that their concentrations have reduced, this increase is probably due to changes in foliar leaching and uptake of nitrate and ammonium. The mechanism of this is discussed further below.

\section{Table 2 near here}

Table 2 shows how weekly concentrations of the measured ions correlate with each other in precipitation and throughfall over the two study periods. In rain, the relationships between acidity $\left(\mathrm{H}^{+}\right.$concentration) and nitrate and sulphate have weakened over time. The strong correlations between ammonium and nitrate and ammonium and sulphate have, however, remained broadly the same, probably reflecting formation and washout of ammonium sulphate and ammonium nitrate aerosols as important processes in both periods. In throughfall, the relationship between acidity and sulphate has weakened, and that between acidity and nitrate has disappeared. In contrast, the relationships between ammonium and 
nitrate and ammonium and sulphate have strengthened considerably. These patterns are consistent with measured and hypothesized changes in atmospheric chemistry over this time period (e.g. Fowler et al., 2001, 2005; Fagerli and Aas, 2008). These are a reduction in $\mathrm{SO}_{2}$ concentration, which will reduce concomitant $\mathrm{H}^{+}$concentrations in throughfall; an increase in the deposition velocity of $\mathrm{SO}_{2}$ due to a reduction in the $\mathrm{SO}_{2} / \mathrm{NH}_{\mathrm{x}}$ ratio, leading to a stronger relationship between ammonium and sulphate in throughfall; and an increase in ammonium nitrate formation at the expense of $\mathrm{NO}_{\mathrm{x}}$ and nitric acid (Fagerli and Aas, 2008), which will strengthen the relationship between ammonium and nitrate.

In 1979-1982, deposition of both nitrate and ammonium was lower in throughfall than rain (Figures 2 and 3): nitrate $402 \mathrm{eq} \mathrm{ha}^{-1} \mathrm{yr}^{-1}\left(5.6 \mathrm{~kg} \mathrm{~N} \mathrm{ha}^{-1} \mathrm{yr}^{-1}\right)$ in rain; $242 \mathrm{eq} \mathrm{ha}^{-1} \mathrm{yr}^{-1}(3.4 \mathrm{kgN}$ $\left.\mathrm{ha}^{-1} \mathrm{yr}^{-1}\right)$ in throughfall; ammonium $416 \mathrm{eq} \mathrm{ha}^{-1} \mathrm{yr}^{-1}\left(5.8 \mathrm{~kg} \mathrm{~N} \mathrm{ha}^{-1} \mathrm{yr}^{-1}\right)$ in rain; $298 \mathrm{eq} \mathrm{ha}^{-1} \mathrm{yr}^{-}$ ${ }^{1}$ (4.2 $\mathrm{kg} \mathrm{N} \mathrm{ha}^{-1} \mathrm{yr}^{-1}$ ) in throughfall. In 2002, under the same trees, deposition of nitrate was higher in throughfall than in rain, and ammonium about the same (Figures 2 and 3): nitrate $255 \mathrm{eq} \mathrm{ha}^{-1} \mathrm{yr}^{-1}\left(3.6 \mathrm{~kg} \mathrm{~N} \mathrm{ha}^{-1} \mathrm{yr}^{-1}\right)$ in rain; $476 \mathrm{eq} \mathrm{ha}^{-1} \mathrm{yr}^{-1}\left(6.7 \mathrm{~kg} \mathrm{~N} \mathrm{ha}^{-1} \mathrm{yr}^{-1}\right)$ in throughfall; ammonium eq $\mathrm{ha}^{-1} \mathrm{yr}^{-1}\left(3.4 \mathrm{~kg} \mathrm{~N} \mathrm{ha}^{-1} \mathrm{yr}^{-1}\right)$ in rain; 223 eq ha $\mathrm{yr}^{-1}\left(3.1 \mathrm{~kg} \mathrm{~N} \mathrm{ha}^{-1} \mathrm{yr}^{-1}\right)$ in throughfall. Under different trees in 1999-2003, throughfall deposition was consistently greater than rainfall for both nitrate and ammonium (Figures 2 and 3). It has been known for a long time (e.g. Parker, 1983) that the nitrogen component of throughfall is the net result of a number of processes: wet deposition, dry deposition of N-containing gases and particulates, foliar uptake and leaching of nitrate and ammonium, and uptake, leaching and transformations due to epiphytes growing on tree surfaces. Any evaluation of the origin of the change in $\mathrm{N}$ cycling must therefore be somewhat speculative. The correlation patterns discussed in the previous paragraph suggest that dry deposition is likely to be the source of the additional nitrogen. The principal sources of dry deposition are ammonia, nitrogen oxides 
$\mathrm{NO}_{\mathrm{y}}\left(\mathrm{NO}, \mathrm{NO}_{2}, \mathrm{HONO}\right.$ and nitric acid vapour, of which the latter is likely to be the largest component), and ammonium sulphate and ammonium nitrate aerosols. Of these, only $\mathrm{NO}_{2}$ and $\mathrm{NH}_{3}$ were measured directly in the catchment using diffusion tubes, and only in 2001-3. In this period $\mathrm{NH}_{3}$ concentrations were (mean \pm S.D. of 4 -weekly values) $1.1 \pm 0.9 \mu \mathrm{g} \mathrm{m}^{-3}$ and $\mathrm{NO}_{2}$ concentrations $9.7 \pm 5.0 \mu \mathrm{g} \mathrm{m}^{-3}$. Though the $\mathrm{NH}_{3}$ concentration was low, this nevertheless would equate to a deposition of $8.6 \mathrm{~kg} \mathrm{~N} \mathrm{ha}^{-1} \mathrm{yr}^{-1}$ at a dry deposition velocity of $0.03 \mathrm{~mm} \mathrm{~s}^{-1}$ (Cape et al., 2008). $\mathrm{NO}_{2}$ deposition equates to $1.9 \mathrm{~kg} \mathrm{~N} \mathrm{ha}^{-1} \mathrm{yr}^{-1}$ at a dry deposition velocity of $0.002 \mathrm{~mm} \mathrm{~s}^{-1}$. For the other components, indications are available from modelling. In 2002, using the UK Lagrangian trajectory model FRAME, oxidised $\mathrm{N}$ wet deposition to this area was estimated as about $3 \mathrm{~kg} \mathrm{~N} \mathrm{ha}^{-1} \mathrm{yr}^{-1}$ and dry deposition as just over $5 \mathrm{~kg} \mathrm{~N} \mathrm{ha}^{-1} \mathrm{yr}^{-1}$. For reduced $\mathrm{N}$, the corresponding figures were 4.5 and $4.5 \mathrm{~kg} \mathrm{~N} \mathrm{ha}^{-1} \mathrm{yr}^{-1}$ respectively. Retrospective modelling of the situation in 1970 using FRAME (Matejko et al., 2009) showed oxidised $\mathrm{N}$ wet deposition of about $5 \mathrm{~kg} \mathrm{~N} \mathrm{ha}^{-1} \mathrm{yr}^{-1}$ and dry deposition as considerably greater than $5 \mathrm{~kg} \mathrm{~N} \mathrm{ha}^{-1} \mathrm{yr}^{-1}$. For reduced $\mathrm{N}$, the corresponding figures were about 4 and $5 \mathrm{~kg} \mathrm{~N} \mathrm{ha}^{-1} \mathrm{yr}^{-1}$ respectively. FRAME works on a 5 x $5 \mathrm{~km}$ grid, so both emissions and deposition are averaged over this area. Dry deposition estimated at a point from concentration measurements is thus not necessarily going to be the same as a grid average, even if the model were perfectly accurate. For instance, there may be an emission source relatively close which increases the actual point deposition. Ammonium dry deposition in 2002 was estimated as being higher than FRAME predicted (8.6 versus $4.5 \mathrm{~kg}$ $\mathrm{N} \mathrm{ha}^{-1} \mathrm{yr}^{-1}$ ). Deposition of $\mathrm{NO}_{2}$ was estimated to be lower than oxidised $\mathrm{N}$ predicted by FRAME (1.9 versus $\left.3 \mathrm{~kg} \mathrm{~N} \mathrm{ha}^{-1} \mathrm{yr}^{-1}\right)$, but the latter includes a contribution from nitric acid deposition which was not measured directly. However, the point remains valid that dry deposition is likely to have gone down between the sampling periods, especially for oxidised $\mathrm{N}$ which has a longer transport distance, even though measurements show values somewhat 
removed from model predictions. It interesting to note that modelled dry deposition of $\mathrm{N}$ in 1999 - 2002 still exceeded the measured throughfall deposition.

It therefore seems likely that changes in foliar uptake explain the increase in $\mathrm{N}$ deposition in throughfall between the two deposition periods. Foliar uptake of both oxidised and reduced $\mathrm{N}$ species is known to be an important process (Sparks, 2009). Foliar N uptake may have declined because soil nitrogen is becoming more available in the catchment. A decreasing $\mathrm{C} / \mathrm{N}$ ratio of the forest floor is a marker for increased soil $\mathrm{N}$ availability and nitrate leaching (Gundersen et al., 1998). Whitehead et al. (2002) showed that the $\mathrm{C} / \mathrm{N}$ ratio of humus in the same area of the catchment as the throughfall collectors decreased from 39 to $26 \mathrm{~mol} \mathrm{~mol}^{-1}$ between the two study periods, and mean nitrate concentrations in the output stream more than doubled (Hill et al., 2002). Another reason is that as the trees were 80 rather than 60 years old in the second period, their nitrogen requirements would be smaller (e.g. Miller, 1995). This combination of smaller requirement and greater soil availability may have led to reduced foliar uptake and increased throughfall deposition.

\subsection{CAUSES OF HIGH ACIDITY IN SCOTS PINE THROUGHFALL}

\section{Figure 6 near here}

In 1979-1982, throughfall under the Scots pines was extremely acidic, with a mean $\mathrm{pH}$ consistently below 3.0, averaging 2.84 over the three years of study (Figure 5). Under deciduous trees the acidity was less extreme, the 3-year mean $\mathrm{pH}$ being 3.70 for birches, 3.84 for oaks, and 4.27 for bracken. For a 6-week period from 17 February 1983, before the deciduous trees had produced leaves, all the major ions in throughfall and rain were analysed, allowing the source of the acidity to be investigated. The results are shown in Figure 6, which also shows the same ions under the same Scots pine trees in 1999-2003, scaled to the same 
units. Anions and cations are shown in separate bars. Capture of $\mathrm{NaCl}$ from seasalt aerosols provided a large but neutral contribution to the ion balance. The main difference between the Scots pines and the deciduous trees was that the former were much better at capturing $\mathrm{SO}_{2}$ from the atmosphere. Some of the resulting sulphuric acid was neutralised by leaching of base cations, with possibly a contribution from the capture of atmospheric aerosols, but the trees were not able to supply base cations at a sufficiently high rate, leaving the ion balance to be made up by $\mathrm{H}^{+}$, and hence producing a low $\mathrm{pH}$. The deciduous trees in the leafless season were not markedly better than Scots pine at supplying base cations, but the lower sulphur flux generated less acidity to neutralise, hence the $\mathrm{pH}$ was still acidic but not so extreme. In 19992003, the Scots pines could supply enough base cations effectively to neutralise the much reduced flux of acidity associated with sulphate and nitrate.

This raises the question of why the deposition of $\mathrm{SO}_{2}$ in 1979-2003 was so high in the first place. This area would not be thought of as a particularly polluted part of the UK either in the late 1970 s or the early 2000 s, so the high deposition rates require explanation. Retrospective modelling using FRAME by Matejko (2009), displayed as a map, shows that the Tillingbourne area in 1970 was on the very southern edge of the area of highest $\mathrm{S}$ deposition in the UK, with both wet and dry deposition rates of $20 \mathrm{~kg} \mathrm{~S} \mathrm{ha}^{-1} \mathrm{yr}^{-1}$ (1250 eq ha ${ }^{-1}$ $\left.\mathrm{yr}^{-1}\right)$. This should thus have given total deposition of about $2500 \mathrm{eq} \mathrm{ha}^{-1} \mathrm{yr}^{-1}$ on the grid square average vegetation (mostly forest) as opposed to the $5900 \mathrm{eq} \mathrm{ha}^{-1} \mathrm{yr}^{-1}$ observed in throughfall (Fig. 3). The additional deposition might thus be related to the fact that these trees were unusually effective at collecting dry deposition, or be a sampling artefact (funnels located under drip points, for instance, though the low volumes (Fig. 3) suggest that is not the case). Alcock and Morton (1981) reported no enhancement of sulphate deposition in throughfall compared to bulk precipitation under 30-year old Scots pines in a 2-year study 
near Ascot, only about $30 \mathrm{~km}$ distant from the present site, in the years 1975-77. However, this was a dense plantation of young trees with a density of about 1 tree per $4 \mathrm{~m}^{2}$. The Tillingbourne trees were larger; for the two "old" Scots pines the distance to the nearest neighbour was about $10 \mathrm{~m}$ and $12 \mathrm{~m}$ respectively as opposed to $2 \mathrm{~m}$ for Alcock and Morton's trees; and the Tillingbourne trees had many dead branches which are effective at collecting dry deposition but less effective than leaves at supplying neutralising base cations. The high rates of deposition under the Tillingbourne Scots pines are thus probably an example of the crucial role of canopy structure in determining throughfall inputs (e.g. Levia and Frost, 2006), reminiscent of the high rates of throughfall deposition observed at forest edges due to increased turbulence (e.g. Beier and Gundersen, 1989).

\subsection{COMPARISONS BETWEEN TREE SPECIES, 1979-1982}

\section{Figure 7 near here}

In 1979-82, throughfall was collected under bracken, birch and oak as well as Scots pine. Figure 7 shows deposition under all species as the mean of the three years of collection. In most respects, birch and oak react in a fashion intermediate between rain and pine throughfall. Interception loss $(25 \%)$ was not as great as with pine (64\%). Sulphate deposition was enhanced in throughfall, but not as much as in pine. Free $\mathrm{H}^{+}$deposition was only somewhat enhanced, showing that the deciduous trees were better able to neutralize the incoming acids than the pines. There are two explanations for this: the acid flux was smaller; and the deciduous trees were better able to supply neutralizing substances such as base cations and organic acids. Figure 7 shows that the fulvic acid content of oak and birch throughfall was slightly but not significantly higher than that of pine. The deciduous trees absorbed nitrate to about the same extent as the pines, but they were less efficient at absorbing ammonium. De Schrijver et al. (1997), in a survey of 38 different studies, noted that "in regions with relatively low open field deposition of atmospheric $\mathrm{N}\left(<10 \mathrm{~kg} \mathrm{~N} \mathrm{ha}^{-1} \mathrm{yr}^{-}\right.$ 
${ }^{1}$ ), lower NH4+ mean throughfall (+stemflow) deposition was, however, reported under conifers compared to deciduous forest, while in regions with high atmospheric $\mathrm{N}$ pollution (>10 kg N ha ${ }^{-1} \mathrm{yr}^{-1}$ ) the opposite could be concluded". The Tillingbourne open field deposition was just above this boundary $\left(11 \mathrm{~kg} \mathrm{~N} \mathrm{ha}^{-1} \mathrm{yr}^{-1}\right)$, but the tree behaviour was characteristic of the lower pollution regions.

Also shown on Figure 7 is bracken, which differs from the trees in dying down below the level of the throughfall collector every winter. There was $12 \%$ interception loss, and no enhancement of sulphate deposition, probably due to the position of the plant under the general tree canopy (even though there were no trees immediately above the collectors). Bracken throughfall was slightly less acid than rainfall and, surprisingly, did not have a high organic (fulvic acid) content. There was evidence of uptake of nitrate but not of ammonium. Carlisle et al. (1967) also found N uptake by bracken in an oak (Quercus petraea) wood in northern England, and a comparable amount of interception loss. Williams et al. (1987) found a somewhat higher interception loss $(20 \%)$ in a non-forested bracken stand at an upland site, but a similar increase in $\mathrm{pH}$. Bracken and similar understorey vegetation cannot be ignored in nutrient cycling studies.

\section{Table 3 near here}

Table 3 shows differences in the seasonal pattern of throughfall gains and losses (throughfall - bulk precipitation) between winter (November to February) and summer (June to August). Interception loss was greater in summer for all species, as would be expected. The deciduous trees were able to neutralize the incoming acidity when in leaf in summer, but not in winter, whereas the pines were unable to neutralize the (greater) flux of acidity in either season. Neutralization thus depends on leaching of bases or buffering substances from the leaves, rather than reactions of the epiphytes or microbial flora. Fulvic acid leaching increased in 
summer from the deciduous trees. The gain in sulphate in throughfall is greater in winter than summer for the deciduous trees, probably because of the higher $\mathrm{SO}_{2}$ concentrations in winter, although, surprisingly, this effect was not seen in the pines. All species of tree absorbed nitrate in both winter and summer, showing that some was absorbed by structures other than foliage. This could be epiphytes and/or twigs and branches -e.g. Wilson and Tiley (1998) showed that branches of young Norway spruce were more effective than needles at absorbing labeled nitrate. There was no significant difference between summer and winter apparent absorption rates, though there appeared to be a trend (significant for the pines) of greater absorption in summer. For ammonium there were no clear trends or significant differences.

\subsection{IMPLICATIONS}

As throughfall is an important component of nutrient cycling, these changes are likely to alter the reactions of the catchment as a whole. There is ample evidence that the composition of throughfall and its spatial pattern has a profound effect on the soil and soil solution (e.g. Boxman et al., 2008; De Schrijver et al., 2007; De Vries et al., 2003; Moffat et al., 2002). The effects extend even into shallow groundwater - e.g. Böttcher et al.(1997) showed that groundwater kept a memory of S deposition four years earlier. In the Tillingbourne catchment, Skeffington (1983) showed that isolated trees created a saucer-shaped depression of $\mathrm{pH}$ around the trunk, though base cations were not depressed. In this context, an increase in throughfall $\mathrm{pH}$ from a mean of 2.85 in $1979-82$ to 4.30 in $1999-2003$ would be expected to have a large effect on the soil micro-organisms and their metabolism. Vanguelova et al. (2009) reviewed 12 years of data from 10 sites in the UK, and showed among other things that soil DOC had increased, probably a consequence of increased microbial metabolism. A widespread increase in DOC in freshwaters in Europe and North America has been attributed to increased microbial metabolism consequent on $\mathrm{S}$ deposition reduction (Evans et al., 2006), though as Roulet and Moore (2006) pointed out, the complexity of the routes of passage of 
DOC through the landscape implies that other explanations, such as those involving climate change, cannot be ruled out at present. Climate change will clearly interact with nutrition changes, but the potential effects of climate change on throughfall nutrient cycling are only just starting to be explored.

The increased $\mathrm{N}$ flux in throughfall may also be expected to have consequences for nutrient cycling, increasing the $\mathrm{N}$ status of the forest floor, for instance. The change is smaller than that for S, and this fits the general pattern observed in the UK. For instance, Vanguelova et al. (2009) in a study of 10 sites across the UK from 1995 to 2006, observed throughfall sulphate reductions in all of them, but variable and insignificant changes of nitrate, plus ammonium reductions at a few sites. Changes in soil solution $\mathrm{N}$ were also variable. This contrasts with the situation in The Netherlands (e.g. Boxman et al., 2008) - here strenuous efforts have been made to reduce ammonium deposition, leading to a decline in $\mathrm{N}$ concentrations in the soil solution. At the Tillingbourne, the catchment is still absorbing most of the incoming $\mathrm{N}$ (Hill et al., 2002), but the slightly increased $\mathrm{N}$ concentrations in throughfall may have made a contribution to the observed increase in $\mathrm{N}$ concentrations in the output stream (Hill et al., 2002).

\subsection{NUTRIENT CYCLING IN THROUGHFALL 1999-2003}

\section{Table 4 near here}

Table 4 shows measured fluxes for all the measured ions in bulk precipitation, throughfall, and the difference between the two for the Scots pine trees in 1999-2003. Positive differences indicate a gain in throughfall, and most values are positive except for free $\mathrm{H}^{+}$, which is negative except for 2002-3, indicating lower acidity under the canopy than in the open. This is borne out by two other measures of acidity: the measured alkalinity and the calculated acid 
neutralising capacity (ANC: Reuss and Johnson, 1996) which are both notably less negative under the tree canopy except in 2002-3. Positive differences between throughfall and precipitation reflect the major sources of deposition and canopy leaching as noted in numerous other studies of throughfall, reviewed for instance by Parker (1983) and Levia and Frost (2006). Seasalt-derived fluxes of sodium and chloride dominate the ion balance, and seasalt deposition also accounts for $92 \%$ of the magnesium in throughfall and $24 \%$ of the sulphate. The remaining non-marine sulphate is due to pollutant deposition (as $\mathrm{SO}_{2}$ and ammonium sulphate aerosol - see Table 2) - this was still a noteworthy component even with the large reduction in precursor gas emissions.

Only $6 \%$ of the potassium and $17 \%$ of the calcium are derived from seasalt, the rest presumably being leached from the canopy in the case of potassium and a mixture of leaching and dust deposition for calcium. The gain of ammonium and nitrate in throughfall from dry deposition ought to be larger than it is (see above) so there is likely to be some foliar and epiphyte uptake reducing concentrations. Manganese is probably mostly leached, while aluminium and iron are likely to be soil-derived deposition (e.g. Herrman et al., 2006; Parker, 1983). Enhancements of the trace elements strontium, barium, copper and zinc are small but positive. Finally, dissolved organic carbon is considerably enhanced in throughfall, reflecting such processes as decomposition of plant, epiphyte and microbial material, release of sugars by insects, and direct leaching from the plant (e.g. Parker, 1983; Stadler et al., 2001).

\section{Conclusions}

The results presented in this paper are explicable in terms of known processes, though it should not be forgotten that they are derived from relatively few throughfall collectors and apply to trees in a specific situation, that is relatively large trees in open canopy. They are not 
necessarily representative of the catchment as a whole. The number of throughfall collectors needed to estimate element fluxes on a catchment scale with reasonable precision can be very large (e.g. Kimmins, 1973), especially when, as here, there are a number of species and the canopy is open and varied. Resource constraints mean such studies are rarely possible. Bulking the samples from a number of collectors before analysis, as in 1999-2003, reduces the analytical load and improves representativeness, but precludes any statistical estimates of precision or accuracy. These results are thus best looked on as a study of the responses of individual trees to a change in pollution climate, rather than that of a catchment area. The large reduction in $\mathrm{SO}_{2}$ emissions in the 20 years between sets of measurements has caused a profound change in nutrient cycling. In 1979-82, the Scots pine trees were unable to supply enough neutralising capacity in the form of base cations or organic buffers to neutralise the incoming flux of sulphuric acid, and consequently the $\mathrm{pH}$ was extremely low. This also applied to the deciduous trees in the leafless season, but in summer they were just able to neutralise the flux of sulphate-associated acidity, which was lower than that of the pines possibly because of their smaller surface area. In 1999-2003, the pines were largely able to neutralise the much lower flux of sulphate-associated acidity, and the $\mathrm{pH}$, though still acid, returned to more normal levels.

Wet $\mathrm{N}$ deposition declined between the two study periods and models indicate that dry deposition did also. However, the throughfall flux of nitrate and (probably) ammonium increased. The most likely explanation for this is that foliar uptake of combined nitrogen decreased, possibly mediated by the increasing nitrogen saturation of the catchment as noted by Whitehead et al. (2002). The throughfall flux of $\mathrm{N}$ was still less than modelled wet plus dry deposition, even in 1999-2003. 
It would be interesting to know if these trends have continued given the further reductions in S and N emissions (NAEI, 2011) since this study was completed. In the early 1980s, individual trees had a clear effect on soil chemistry (Skeffington, 1983) in which soils under pines had a lower $\mathrm{pH}$ but increased base cations compared to deciduous trees - the observed changes in throughfall reported in this paper might be expected to reduce these differences, with consequent effects on soil microbial populations and nutrient metabolism in soils, which might in turn have consequences for element export to the drainage stream. The interaction of all these processes with climate change could provide another fruitful area of study if, as predicted, temperatures start to rise and precipitation declines in this area (UKCP09, 2011). The work described in this paper, and in Hill et al. (2002), provides a baseline against which these changes could be judged.

\section{Acknowledgements}

This study was funded by two now defunct arms of the UK Government: the Central Electricity Generating Board (1977-82) and the Department of Trade and Industry (19992003). They had no influence on the study design, the collection, analysis and interpretation of data, the report writing or the decision to submit this paper for publication. We would like to acknowledge the hard work of Mike Russell (1977-82) and Sue Cumberland (1999-2003) who performed the bulk of the chemical analysis described. The National Trust and Wotton Estate kindly gave permission for this work to be carried out on their land.

\section{References}

Alcock MR, Morton AJ. The sulphur content and $\mathrm{pH}$ of rainfall and of throughfalls under pine and birch. J Appl Ecol 1981; 18: 835-839.

Beier, C., Gundersen, P. Atmospheric deposition to the edge of a spruce forest in Denmark. Env Poll 1989; 60: 257-271. 
Böttcher J, Lauer S, Strebel O, Puhlmann M. Spatial variability of canopy throughfall and groundwater sulfate concentrations under a pine stand. J Environ Qual 1997; 26: 503-510.

Boxman AW, Peters RCJH, Roelofs JGM. Long term changes in atmospheric N and S throughfall deposition and effects on soil solution chemistry in a Scots pine forest in the Netherlands. Environ Poll 2008; 156: 1252-9.

Cape JN, Jones MR, Leith ID, Sheppard LJ, van Dijk N, Sutton MA, Fowler D, Estimate of annual NH3 dry deposition to a fumigated ombrotrophic bog using concentration-dependant deposition velocities. Atmos Environ 2008; 42: 6637-46.

Carlisle A, Brown AHF, White EJ. The nutrient content of tree stem flow and ground flora litter and leachates in a sessile oak (Quercus petraea) woodland. J Ecol 1967; 55: 615-27.

CEIP Centre on Emission inventories and Projections, Austria, http://www.ceip.at/ [accessed 13 May 2011]

De Schrijver A, Geudens G, Augusto L, Staelens J, Mertens J, Wuyts K, Gielis L, Verheyen K. The effect of forest type on throughfall deposition and seepage flux: a review. Oecologia 2007; 153: 663-674.

De Vries W, Reinds GJ, Vel E. Intensive monitoring of forest ecosystems in Europe 2: Atmospheric deposition and its impacts on soil solution chemistry. Forest Ecol Manage 2003; 174: $97-115$.

Dimmock NA, Garbett K, Webber HM. The use of nitrosulphonazo-III for the absorbtiometric determination of sulphate in high purity power station waters. I. Direct measurement. Power Industry Res 1981; 1: 279-306.

EU Directive 88/609/EEC of 24 November 1988 on the limitation of emissions of certain 
pollutants into the air from large combustion plants. Official J Europ Commun 1988; L336: $1-10$.

EU Directive 2001/81/EC of 23 October 2001 on national emission ceilings for certain atmospheric pollutants. Official J Europ Commun 2001; L309: 1-21.

Evans CD, Chapman PJ, Clark JM, Monteith DT, Cresser MS. Alternative explanations for rising dissolved organic carbon export from organic soils. Global Change Biol 2006; 12 : 2044-53.

Fagerli H, Aas W. Trends of nitrogen in air and precipitation: Model results and observations at EMEP sites in Europe, 1980-2003. Environ Poll 2008; 154: 448-61.

FAO World Reference Map of Soil Resources 2011 http://www.fao.org/ag/agl/agll/wrb/soilres.stm [accessed 21 May 2011].

Fowler, D, Sutton, MA, Flechard, C, Cape, JN, Storeton-West, R, Coyle, M, Smith, RI The control of $\mathrm{SO}_{2}$ dry deposition on to natural surfaces and its effects on regional deposition. Water Air Soil Pollut 2001; Focus 1: 39-48.

Fowler D, Smith RI, Muller JBA, Hayman G, Vincent KJ. Changes in the atmospheric deposition of acidifying compounds in the UK between 1986 and 2001. Environ Poll 2005; 137: $15-25$

Fowler, D, Smith, R, Muller, JBA, Cape, JN, Sutton, M, Erisman, JW, Fagerli, H. Long term trends in sulphur and nitrogen deposition in Europe and the cause of non-linearities, In: Brimblecombe, P Hara, H Houle, D Novak M, editors. Acid Rain - Deposition to Recovery, Dordrecht, Netherlands: Springer; 2007. p.41-7.

Gundersen, P, Emmett, B. A., Kjonaas, O. J., Koopmans, C. J., and Tietema, A. Impact of 
nitrogen deposition on nitrogen cycling in forests - a synthesis of NITREX data. Forest Ecol Manage 1998; 101: 37-55.

Hall, DJ The precipitation collector for use in the secondary national acid deposition network. Report LR 561 (AP) Stevenage, UK: Warren Spring Laboratory; 1986. Available from AEA Technology, Harwell, Didcot, OX11 0QR, UK.

Herrmann M, Pust J, Pott R The chemical composition of throughfall beneath Oak, Birch and Pine canopies in Northwest Germany. Plant Ecol 2006; 184: 273-85.

Hill TJ, Skeffington RA, Whitehead PG. Recovery from acidification in the Tillingbourne Catchment, southern England: catchment description and preliminary results. Sci Tot Environ 2002; 282-283: 81-97.

Kimmins JP. Some statistical aspects of sampling throughfall precipitation in nutrient cycling studies in British Columbian coastal forests. Ecology 1973; 54: 1008-1019.

Levia DF, Frost EE. Variability of throughfall volume and solute inputs in wooded ecosystems. Progress Physical Geog 2006; 30: 605-32.

Lindberg SE, Lovett GM. Deposition and forest canopy interactions of airborne sulfur results from the Integrated Forest Study. Atmos Environ Part A - General Topics 1992; 26: $1477-92$

Matejko M, Dore AJ, Hall J, Dore CJ, Blas M, Kryza M, et al. The influence of long term trends in pollutant emissions on deposition of sulphur and nitrogen and exceedance of critical loads in the United Kingdom. Environ Sci Policy 2009; 12: 882-96.

McLeod AR, Holland MR, Shaw PJA, Sutherland PM, Darrall NM, Skeffington RA. Enhancement of nitrogen deposition to forest trees exposed to $\mathrm{SO}_{2}$. Nature 1990; 347: 277-9. 
Miller, HG The influence of stand development on nutrient demand, growth and allocation. Plant Soil 1995; 169: 225-32.

Moffat AJ, Kvaalen H, Solberg S, Clarke N. Temporal trends in throughfall and soil water chemistry at three Norwegian forests, 1986-1997. Forest Ecol Manage 2002; 168: 15-28.

NAEI National Atmospheric Emissions Inventory (UK) http://naei.defra.gov.uk/index.php [accessed 12 May 2011].

Parker GG. Throughfall and stemflow in the forest nutrient cycle. Adv Ecol Res 1983; 13: 57-133.

Raat KJ, Draaijers GPJ, Schaap MG, Tietema A, Verstraten JM. Spatial variability of throughfall water and chemistry and forest floor water content in a Douglas fir forest stand. Hydrol Earth System Sci 2002; 6: 363-374.

Reuss JO, Johnson DW. Acid deposition and the acidification of soils and waters. Springer Verlag, New York, 1986.

Roulet N, Moore TR. Environmental chemistry - browning the waters. Nature 2006; 444: 283-4.

Skeffington, R. A. Soil properties under three species of tree in Southern England in relation to acid deposition in throughfall. In: Ulrich, B Pankrath J, editors. Effects of Accumulation of Air Pollutants in Forest Ecosystems. Holland: Reidel Publishing Co; 1983. p.219-231.

Skeffington RA, Sutherland PM. The effects of $\mathrm{SO}_{2}$ and $\mathrm{O}_{3}$ fumigation on acid deposition and foliar leaching in the Liphook forest fumigation experiment. Plant, Cell Environ 1995; 18: $247-61$. 
Sparks JP. Ecological ramifications of the direct foliar uptake of nitrogen. Oecologia 2009; 159: $1-13$.

Stevenson, FJ Humus Chemistry: Genesis, Composition, Reactions. New York: John Wiley \& Sons; 1994.

Stadler B, Solinger S, Michalzik B. Insect herbivores and the nutrient flow from the canopy to the soil in coniferous and deciduous forests. Oecologia 2001; 126: 104-13.

Staelens J, Houle D, De Schrijver A, Neirynck J, Verheyen K. Calculating dry deposition and canopy exchange with the canopy budget model: review of assumptions and application to two deciduous forests. Water Air Soil Pollut 2008; 191: 149-69.

Tamm CO, Cowling EB. Acidic precipitation and forest vegetation. Water Air Soil Pollut 1977; 7: 503-11.

UKCP09 (2011) UK Climate Projections. http://ukclimateprojections.defra.gov.uk/index.php [accessed 17 October 2011].

UNECE The condition of forests in Europe: 2010 Executive Report 2010, http://www.icpforests.org/pdf/ER2010.pdf [accessed 13 May 2011].

UNECE Protocols to the Convention on Long-Range Transboundary Air Pollution 2011, http://www.unece.org/env/lrtap/status/lrtap_s.htm [accessed 8 May 2011].

Vanguelova EI, Benham S, Pitman R, Moffat AJ, Broadmeadow M, Nisbet T, et al. Chemical fluxes in time through forest ecosystems in the UK - soil response to pollution recovery. Environ Pollut 2010; 158: 1857-69.

Whitehead PG, Lapworth DJ, Skeffington RA, Wade AJ. Excess nitrogen leaching and C/N 
decline in the Tillingbourne Catchment, southern England. Hydrol Earth System Sci 2002; 6: 455-66.

Williams AG, Kent M, Ternan JL. Quantity and quality of bracken throughfall, stemflow and litterflow in a Dartmoor catchment. J Appl Ecol 1987; 24: 217-29.

Wilson, E. J, Tiley, C. Foliar uptake of wet-deposited nitrogen by Norway spruce - an experiment using N-15. Atmos Environ 1998; 32, 513-518. 


\section{Legends to Figures}

Fig. 1. A) Situation of the Tillingbourne Catchment, located near the triangle marked "Leith Hill”; B) Detailed map of the catchment. The letters represent sampling sites (see Hill et al., 2002). Rain was collected at Sites F and G, and throughfall in the areas marked H1 and H2.

Fig. 2. Mean annual bulk precipitation deposition for the 3 years beginning 8 February 1979 compared with the 4 years beginning 8 February 1999. Values are the mean of duplicate collectors and are given in equivalents $\left(\mathrm{mol}_{\mathrm{c}}\right) \mathrm{ha}^{-1} \mathrm{yr}^{-1}$. The error bars represent one standard deviation of the variation between sampling years, i.e. 1979-82 or 1999-2003.

Fig.3. Mean annual deposition in Scots pine throughfall for (a) 1979-82 (mean of 2 collectors); (b) 1999-2003 (bulked samples from 4 collectors under different trees to (a)); (c) as for (b) but just for 2002; (d: 2002 old) same trees as for (a) but in 2002. All years began on 8 February. The error bars for (a) and (b) represent one standard deviation of the variation between sampling years, i.e. 1979-82 or 1999-2003 respectively.

Fig 4. Annual mean volume-weighted bulk precipitation concentrations for individual years beginning 8 February 1979 and 8 February 1999. Values are the mean of duplicate collectors.

Fig. 5. Annual mean volume-weighted throughfall concentrations under Scots pine for individual years. The trees in 1979-82 (mean of 2 collectors) were different from those in 1999-2003 (bulked samples from 4 collectors) but the same as those labelled Old SP 2002. All years began on 8 February. 
Fig. 6. Complete ion balance under three species of tree for a 6-week period from 17 February 1983, compared with bulk precipitation in the same period and the "new" Scots pines in 1999-2003. Cations (+) and anions(-) are shown in separate columns.

Fig. 7. Mean volume-weighted concentrations under the different species of tree plus bulk precipitation ("rain") and bracken (Pteridium aquilinum) for the three years beginning 8 February 1979. Error bars indicate one standard deviation, with $n=2$ for rain, bracken and pine and $\mathrm{n}=6$ for oak and birch. 


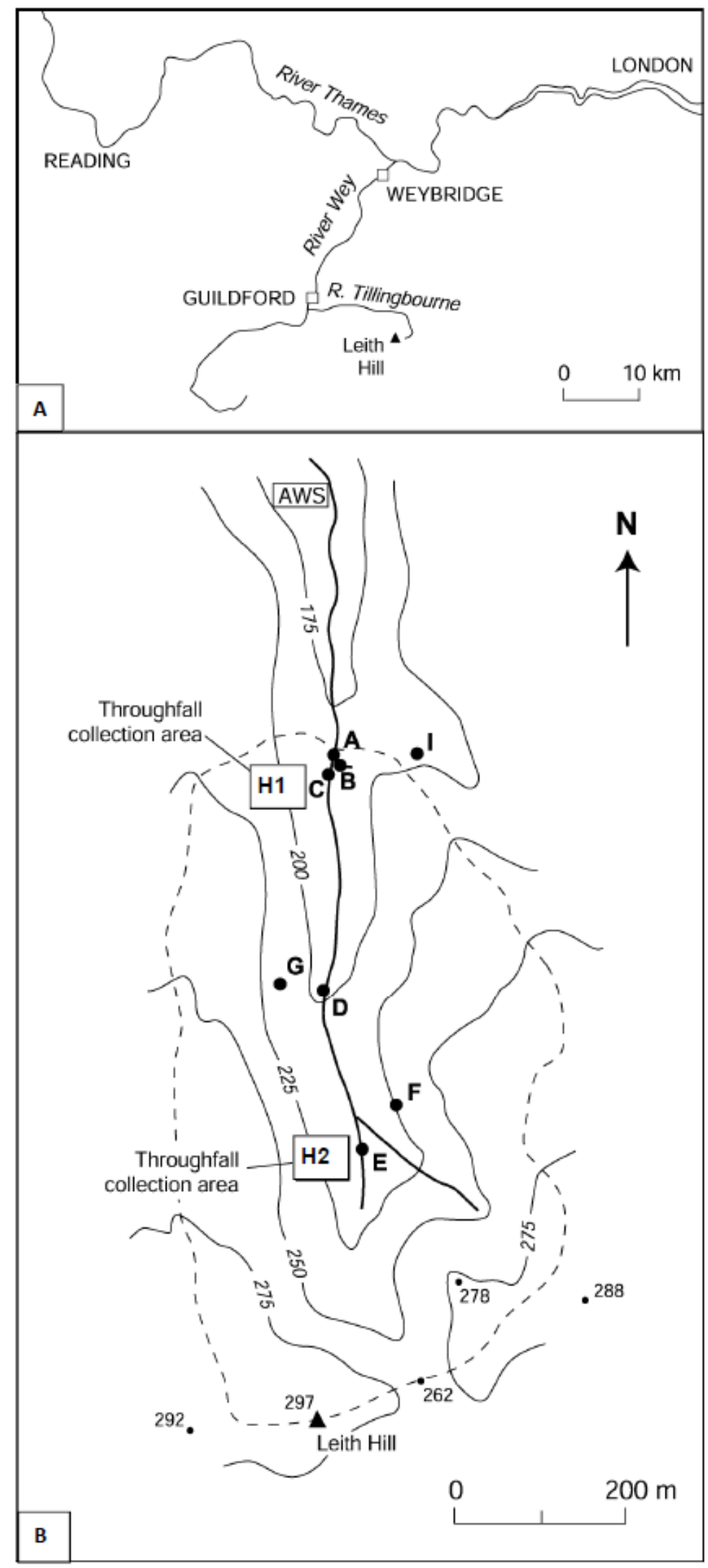

Figure1 


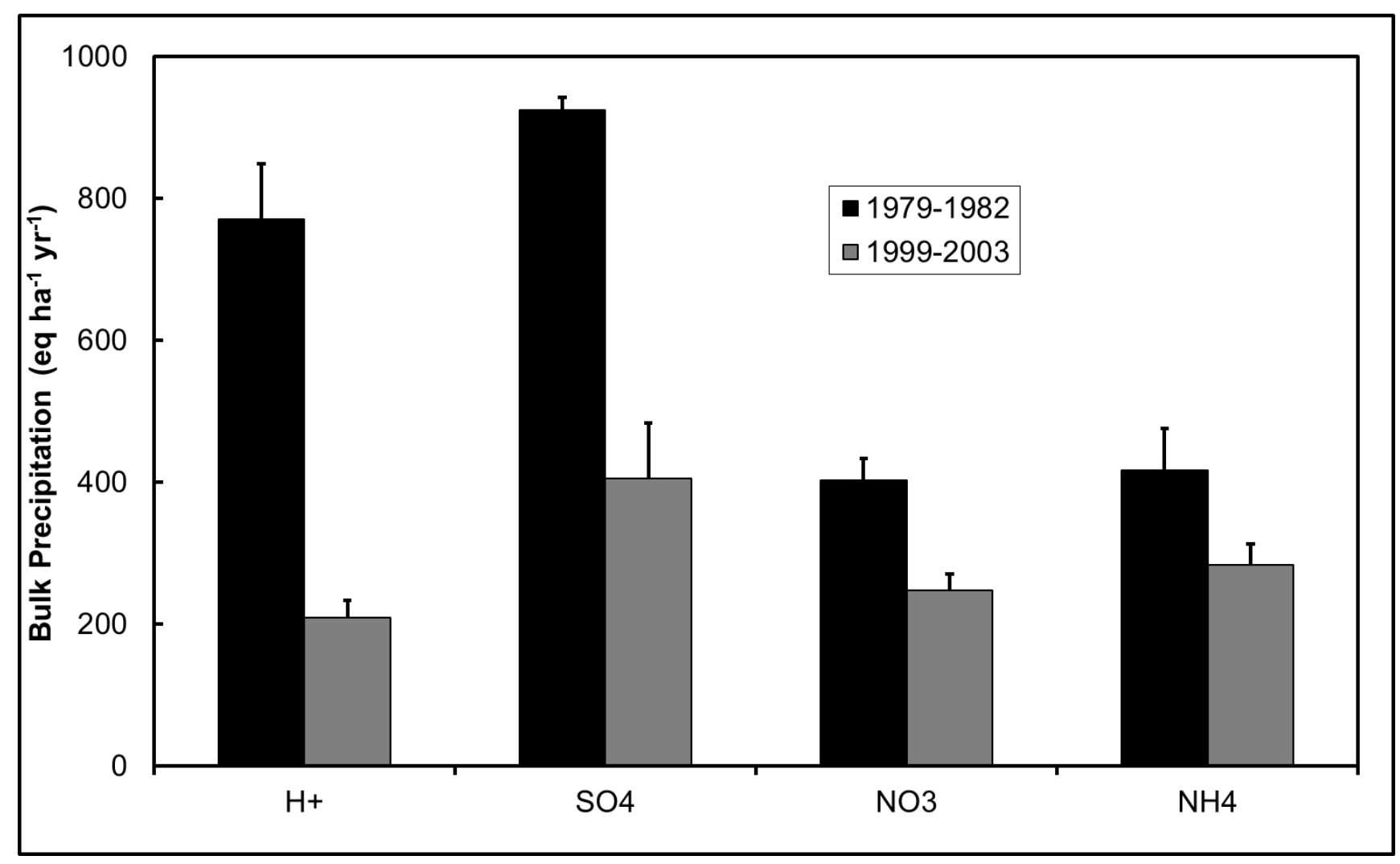

Figure 2. 


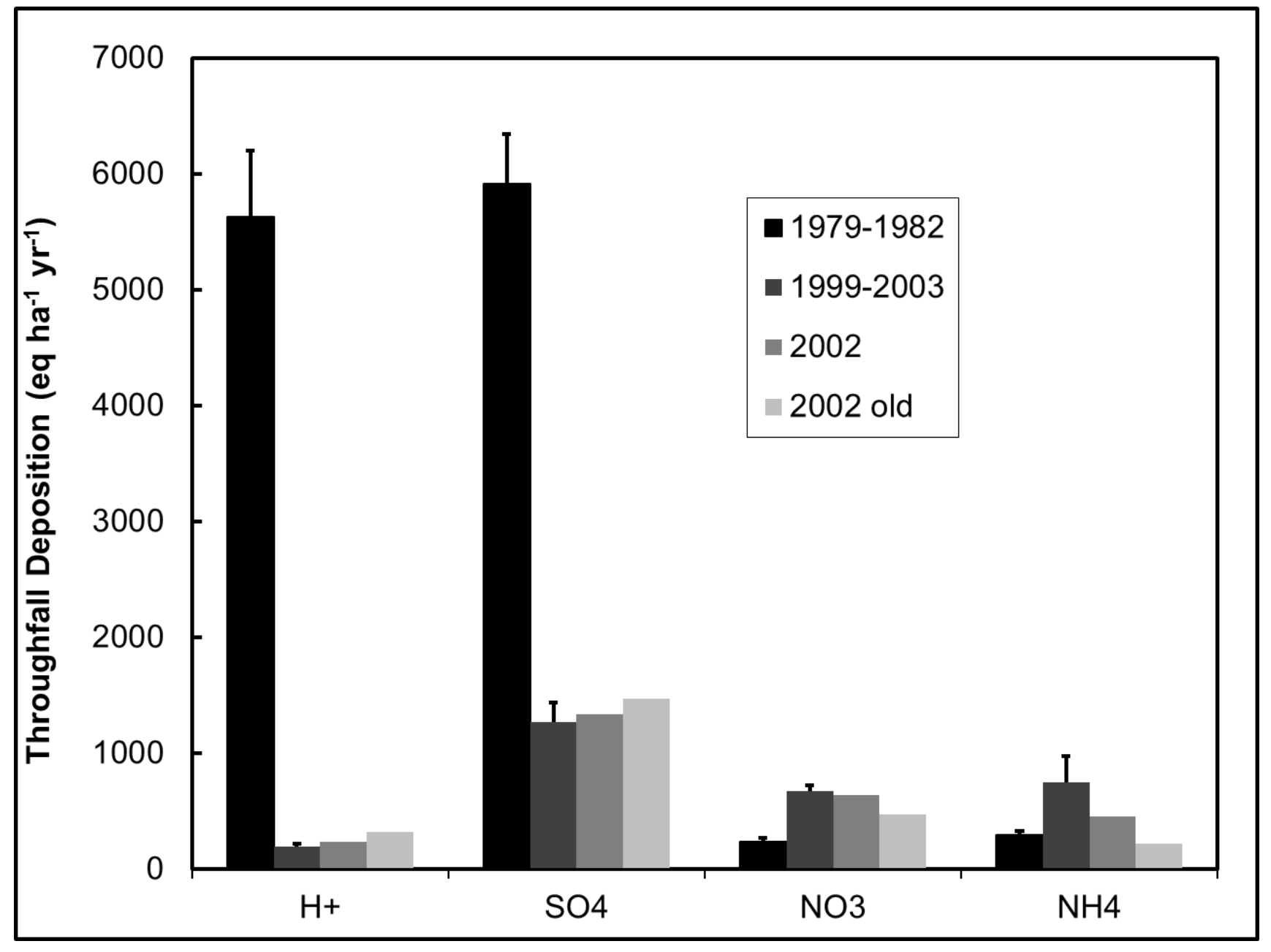

Figure 3 


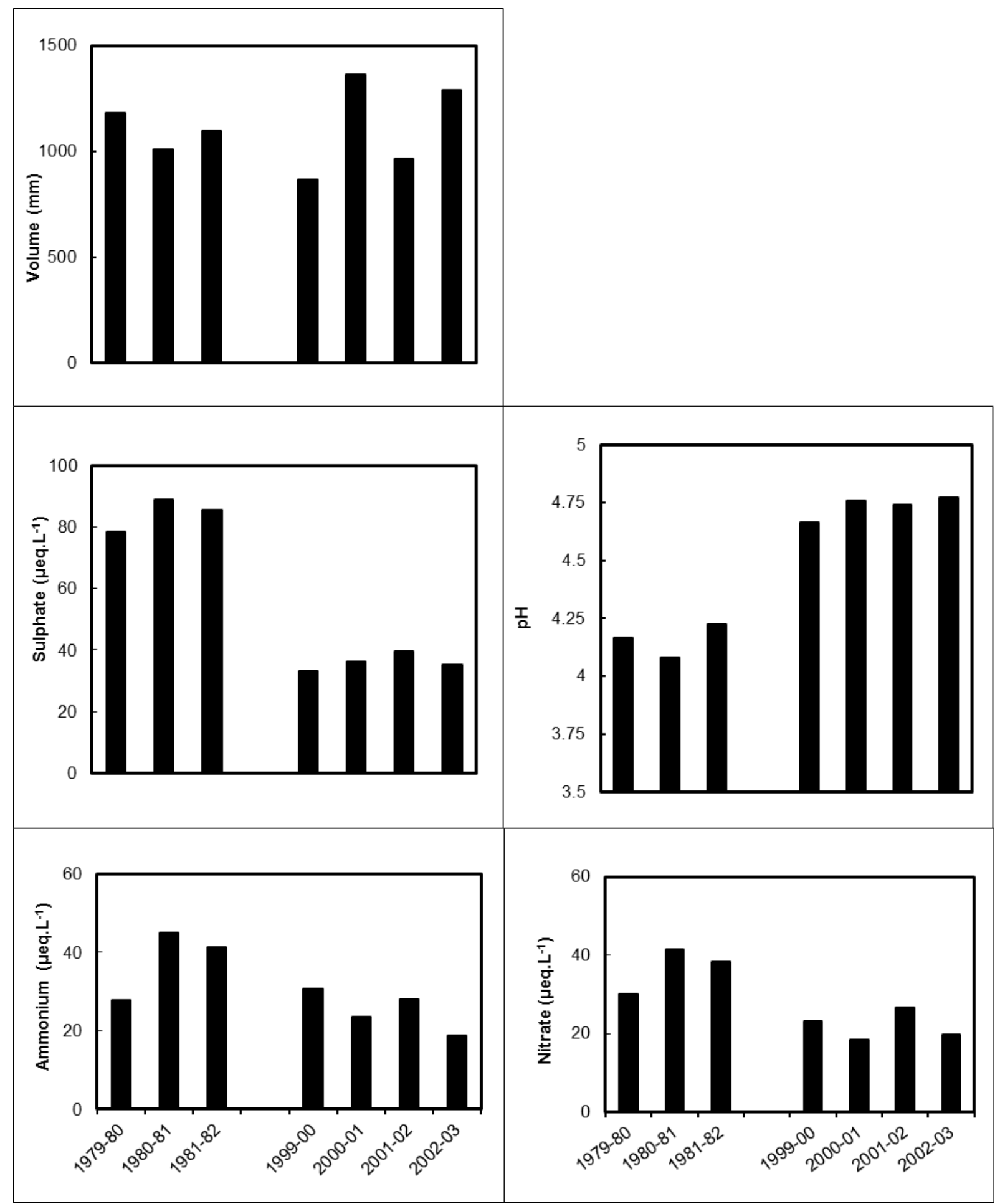

Figure 4 


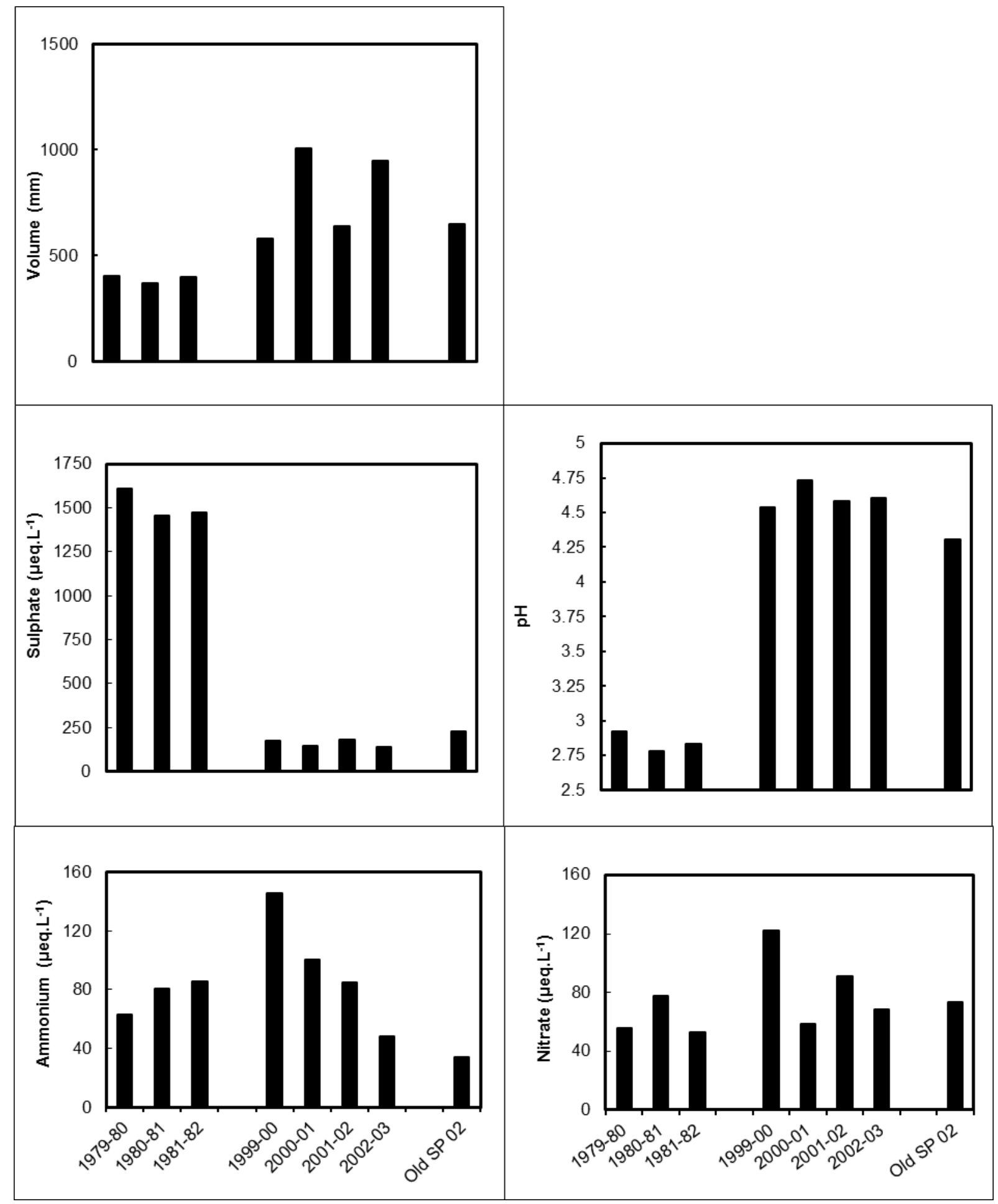

Figure 5 


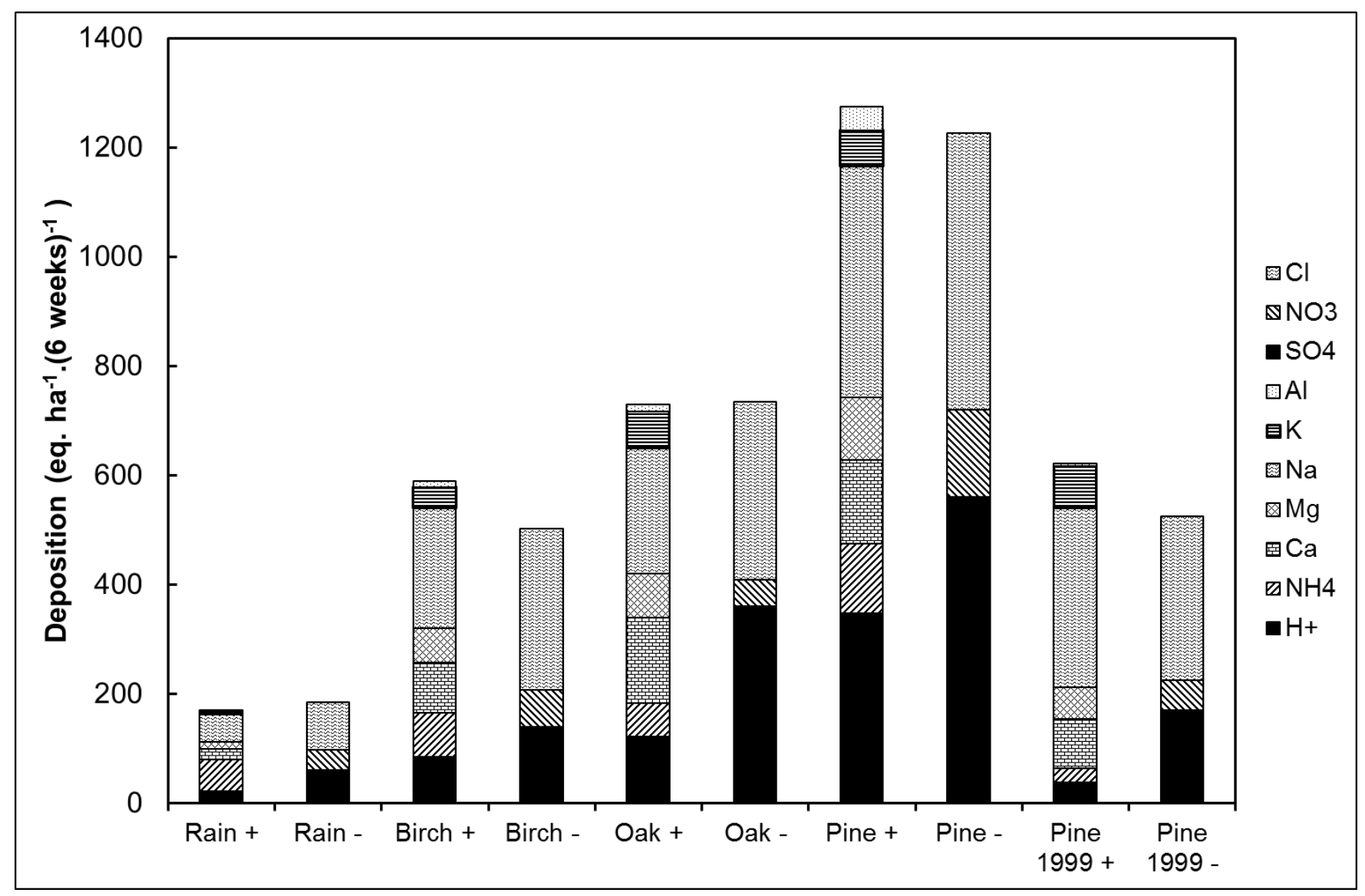

Figure 6 


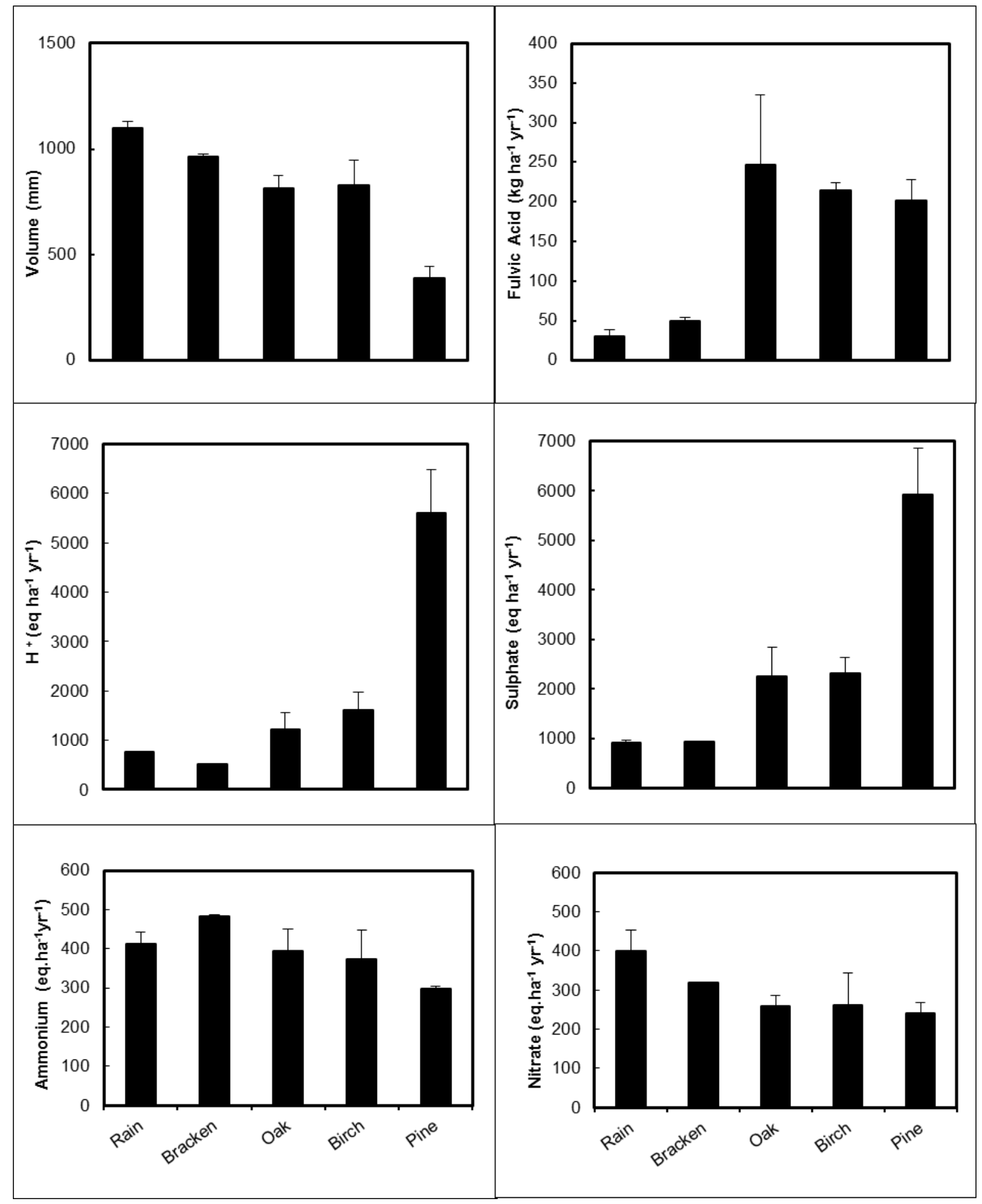

Figure 7 
Tables: Skeffington and Hill

Table 1: Atmospheric Emissions of $S$ and $N$ in the UK, 1979-2003

\begin{tabular}{|c|c|c|c|c|c|c|c|c|c|}
\hline & 1979 & 1980 & 1981 & 1982 & 1999 & 2000 & 2001 & 2001 & 2003 \\
\hline $\mathrm{SO}_{2}$ & 5429 & 4781 & 4359 & 4163 & 1210 & 1226 & 1105 & 978 & 968 \\
\hline$* \mathrm{NO}_{\mathrm{x}}-\mathrm{N}$ & 1241 & 1181 & 1135 & 1124 & 875 & 861 & 841 & 795 & 875 \\
\hline $\mathrm{NH}_{3}-\mathrm{N}$ & & ${ }^{\dagger} 273$ & & & 282 & 271 & 267 & 261 & 253 \\
\hline
\end{tabular}

1. From NAEI (2011). Units are millions of tonnes. Estimated errors are $\pm 4 \%$ for $\mathrm{SO}_{2}$, $\pm 10 \%$ for $\mathrm{NO}_{\mathrm{x}}$, and $\pm 20 \%$ for $\mathrm{NH}_{3}$ (NAEI, 2011). $*$ Converted to $\mathrm{N}$ assuming $5 \%$ of the primary emission is $\mathrm{NO}_{2}$ and $95 \% \mathrm{NO}$. ${ }^{\dagger}$ This figure was obtained from the European Centre on Emission Inventories and Projections (CEIP, 2011). Official UK sources regard ammonia emission data from this period as too unreliable to report. 
Table 2: Correlation Coefficients between Weekly Concentrations of Ions in Rain and Scots Pine Throughfall

\begin{tabular}{llllll}
\hline & Period & $\mathbf{H}^{+}-\mathbf{S O}_{4}{ }^{2-}$ & $\mathbf{H}^{+}-\mathbf{N O}_{3}{ }^{-}$ & $\mathbf{N H}_{4}{ }^{+}-\mathbf{N O}_{3}{ }^{-}$ & $\mathbf{N H}_{4}{ }^{+}-\mathbf{S O}_{4}{ }^{2-}$ \\
\hline Precipitation & $1979-1982$ & $0.654^{* * *}$ & $0.694^{* * *}$ & $0.747^{* * *}$ & $0.790^{* * *}$ \\
& $1999-2003$ & $0.186^{*}$ & $0.481^{* * *}$ & $0.724^{* * *}$ & $0.685^{* * *}$ \\
\hline Throughfall & $1979-1982$ & $0.684^{* * *}$ & $0.256^{*}$ & $0.337 * *$ & 0.019 \\
& $1999-2003$ & $0.210^{* *}$ & -0.043 & $0.813^{* * *}$ & $0.630^{* * *}$ \\
\hline
\end{tabular}

Product-moment correlation coefficients between the pairs of ions indicated. ***, significantly different from zero at $\mathrm{p}<0.001 ; * *, \mathrm{p}<0.01 ; *, \mathrm{p}<0.05$; unlabelled, not significantly different. 
Table 3: Seasonal Patterns of Gain and Loss in Throughfall

\begin{tabular}{|c|c|c|c|c|}
\hline & Season & Oak & Birch & Pine \\
\hline Interception loss & Winter & $\mathbf{0 . 5 5}$ & 0.42 & 0.97 \\
\hline$\left(\mathrm{mm} \mathrm{d}^{-1}\right)$ & Summer & 0.72 & 0.67 & 1.29 \\
\hline $\mathrm{H}^{+}$ & Winter & 3.16 & 5.12 & 8.61 \\
\hline$\left(e q \mathrm{ha}^{-1} \mathrm{~d}^{-1}\right)$ & Summer & -0.88 & 0.66 & 9.57 \\
\hline Fulvic Acid & Winter & 0.24 & 0.20 & 0.40 \\
\hline$\left(\mathrm{kg} \mathrm{ha}^{-1} \mathrm{~d}^{-1}\right)$ & Summer & 1.06 & 0.70 & 0.38 \\
\hline Sulphate & Winter & 5.16 & 5.69 & 9.58 \\
\hline$\left(e q \mathrm{ha}^{-1} \mathrm{~d}^{-1}\right)$ & Summer & 2.43 & 2.47 & 11.04 \\
\hline Nitrate & Winter & -0.30 & -0.19 & -0.03 \\
\hline$\left(e q \mathrm{ha}^{-1} \mathrm{~d}^{-1}\right)$ & Summer & -0.41 & -0.34 & -0.19 \\
\hline Ammonium & Winter & -0.08 & 0.06 & -0.05 \\
\hline$\left(e q \mathrm{ha}^{-1} \mathrm{~d}^{-1}\right)$ & Summer & 0.17 & -0.29 & -0.17 \\
\hline
\end{tabular}

For values in bold, the difference between summer and winter is significant ( $t$-test; $p<0.05$ ). 
Table 4: Annual Fluxes in Bulk Precipitation and Scots Pine Throughfall for 1999-2003.

\begin{tabular}{|c|c|c|c|c|c|c|c|c|c|c|c|c|c|c|c|}
\hline & \multicolumn{5}{|c|}{ Bulk Precipitation } & \multicolumn{5}{|c|}{ Throughfall } & \multicolumn{5}{|c|}{ Difference (Throughfall - Precipitation) } \\
\hline & 1999-00 & $2000-1$ & 2001-2 & 2002-3 & Mean & 1999-00 & 2000-1 & 2001-2 & 2002-3 & Mean & 1999-00 & 2000-1 & 2001-2 & 2002-3 & Mean \\
\hline $\mathbf{H}^{+}$ & 189 & 239 & 176 & 219 & 206 & 168 & 187 & 166 & 235 & 189 & -20 & -52 & -10 & 15 & -17 \\
\hline $\mathbf{K}^{+}$ & 27 & 41 & 40 & 46 & 38 & 845 & 1070 & 655 & 905 & 868 & 817 & 1029 & 614 & 860 & 830 \\
\hline $\mathrm{Ca}^{2+}$ & 114 & 209 & 130 & 108 & 141 & 549 & 690 & 646 & 594 & 619 & 435 & 480 & 515 & 486 & 479 \\
\hline $\mathbf{A l}^{3+}$ & 1.0 & 10.4 & 3.3 & 6.0 & 5.2 & 12.5 & 34.3 & 33.0 & 30.1 & 27.5 & 11.5 & 23.9 & 29.7 & 24.1 & 22.3 \\
\hline $\mathrm{Fe}^{2+}$ & 2.4 & 3.5 & 1.5 & 2.5 & 2.5 & 6.1 & 7.4 & 6.0 & 5.0 & 6.1 & 3.7 & 3.9 & 4.4 & 2.6 & 3.6 \\
\hline $\mathrm{Mn}^{2+}$ & 1.0 & 1.4 & 3.1 & 4.5 & 2.5 & 75.4 & 89.0 & 54.0 & 66.4 & 71.2 & 74.5 & 87.5 & 50.9 & 61.9 & 68.7 \\
\hline $\mathrm{Sr}^{2+}$ & 0.4 & 0.6 & 0.7 & 0.4 & 0.5 & 0.9 & 1.4 & 1.5 & 0.9 & 1.2 & 0.5 & 0.7 & 0.8 & 0.5 & 0.6 \\
\hline $\mathbf{B a}^{2+}$ & 0.3 & 0.5 & 0.2 & 0.2 & 0.3 & 0.3 & 0.5 & 0.5 & 2.5 & 1.0 & 0.1 & 0.1 & 0.4 & 2.4 & 0.7 \\
\hline $\mathrm{Cu}^{2+}$ & 2.8 & 4.8 & 3.6 & 9.3 & 5.1 & 2.8 & 8.4 & 4.4 & 3.6 & 4.8 & -0.1 & 3.6 & 0.8 & -5.7 & -0.3 \\
\hline $\mathrm{NH}_{4}^{+}$ & 266 & 321 & 272 & 242 & 275 & 846 & 1010 & 539 & 456 & 713 & 580 & 688 & 268 & 214 & 438 \\
\hline $\mathrm{NO}_{3}^{-}$ & 203 & 253 & 258 & 255 & 242 & 709 & 588 & 580 & 646 & 631 & 506 & 335 & 323 & 391 & 389 \\
\hline $\mathrm{Cl}^{-}$ & 605 & 1260 & 637 & 1170 & 919 & 2150 & 3690 & 1860 & 3600 & 2830 & 1550 & 2430 & 1220 & 2430 & 1910 \\
\hline $\mathrm{SO}_{4}^{2-}$ & 289 & 494 & 382 & 455 & 405 & 1020 & 1460 & 1140 & 1340 & 1240 & 732 & 964 & 761 & 882 & 835 \\
\hline$* \mathrm{SO}_{4}{ }^{2-}$ & 225 & 361 & 315 & 332 & 308 & 795 & 1071 & 948 & 959 & 943 & 570 & 709 & 633 & 627 & 635 \\
\hline Alk & -381 & -577 & -261 & -386 & -401 & -16 & -78 & 173 & -141 & -16 & 364 & 499 & 435 & 245 & 386 \\
\hline ANC & -297 & -494 & -467 & -486 & -436 & -185 & -256 & -236 & -787 & -366 & 112 & 238 & 231 & -301 & 70 \\
\hline DOC & 9 & 17 & 27 & 22 & 19 & 176 & 138 & 130 & 181 & 156 & 167 & 121 & 103 & 159 & 138 \\
\hline
\end{tabular}

Units: eq $\mathrm{ha}^{-1} \mathrm{yr}^{-1}$ except DOC (dissolved organic carbon) $\mathrm{kg} \mathrm{ha}^{-1} \mathrm{yr}^{-1}$. Equivalents calculated using the ionic charge shown in the Table. $* \mathrm{SO}_{4}{ }^{2-}=\mathrm{non}_{-\mathrm{marine}}$ sulphate assuming all $\mathrm{Cl}^{-}$is marine-derived. Alk $=$measured alkalinity. ANC $=$acid neutralising capacity calculated as $\left(\mathrm{Na}^{+}+\mathrm{K}^{+}+\mathrm{Ca}^{2+}+\mathrm{Mg}^{2+}+\mathrm{NH}_{4}^{+}\right)-\left(\mathrm{SO}_{4}{ }^{2-}+\mathrm{NO}_{3}^{-}+\mathrm{Cl}^{-}\right)$. 
